\title{
2 \\ Customary systems of management and World Heritage in the Pacific Islands
}

\author{
Anita Smith, La Trobe University, Melbourne, Australia \\ Cate Turk, Universität Erlangen-Nürnberg, Erlangen, Germany
}

\begin{abstract}
'My observation ... of the often bewildering scene of contested conservation initiatives for the Marovo Lagoon has enabled me to watch how major international environmentalist organizations have risen and then fallen as their simplistic concept of community proved soundly incompatible with the Marovo people's time honoured ways of organising themselves.' (Hviding 2006:83)
\end{abstract}

\section{Introduction}

In recent decades local communities have been increasingly engaged in protecting heritage sites through the development of new models of conservation practice, such as co-management, joint management and community management. Our interest in heritage conservation in the Pacific leads us to examine a related form of management arrangement, customary management. In this paper we examine how systems of customary land tenure prevalent throughout the region require a method for establishing and managing heritage fundamentally different to that employed in the Yellowstone model of state-managed protected areas, or the co-management of Indigenous landscapes such as that of Uluru-Kata Tjuta in Australia. We suggest a fine distinction between customary systems of management and customary systems used in management; and consider the implications customary land tenure has for governance in heritage management; the definition of heritage values; and the need for sustainable livelihoods.

Our discussion is centred around customary management and the uptake of the UNESCO World Heritage Convention in the Pacific region. Although the Pacific Islands continue to be the least represented geo-cultural region on the World Heritage List, the island communities and governments have made a substantial contribution to the World Heritage process, in expanding the understanding of heritage and through their insistence on the recognition of community and culture as central to all World Heritage initiatives (Smith in press). By examining how this international instrument intersects with local practices that protect places of significance, we highlight the struggles between different ways of conceiving conservation, tensions between local and global conservation agendas as well as the common ground where interests coincide.

\section{World Heritage and Pacific Island states}

Since the mid 1990s the World Heritage Committee has actively sought to increase the representation of the Pacific Islands on the World Heritage List (Smith in press). In a landmark 
decision the Committee inscribed East Rennell Island, in the Solomon Islands, on the World Heritage List in 1998. East Rennell being the first site inscribed in an independent Pacific Island nation and the first site anywhere to be inscribed on natural values under customary ownership and protection (UNESCO 1999; see also Smith 2011). Not until 2008 were there further successful nominations in the Pacific Island states, being the cultural properties of Chief Roi Mata's Domain in Vanuatu and Kuk Early Agricultural Site in Papua New Guinea, followed in 2010 by the inscription of Bikini Atoll in the Republic of the Marshall Islands as a cultural property and the Phoenix Islands Protected Area in Kiribati, a natural property.

The World Heritage system poses a number of challenges for the Pacific Island states. In these developing nations, human, financial and technical resources are very limited, and heritage conservation is a low priority for governments. Most importantly in the context of this paper, the rights of customary land owners are enshrined in the constitutions of many Pacific Islands states, creating tensions in the development of national legislation to protect World Heritage properties (in compliance with the state party's obligations under the World Heritage Convention Representatives of Pacific Island states have argued that the World Heritage Committee must recognise not only these challenges but also the unique character of the region's heritage that is reflected in the inseparable relationship between Pacific Island people and their environments) (Smith and Jones 2007; te Heuheu et al. 2012). A statement to the Committee in 2007, known as the 'Pacific Appeal', identifies key elements that underpin this heritage including the region having amongst the highest proportions of people living within traditional governance systems and land and sea remaining under traditional management of any region of the world:

Protection of our heritage must be based on respect for and understanding and maintenance of the traditional cultural practices, Indigenous knowledge and systems of land and sea tenure in the Pacific. (UNESCO 2007a)

These recommendations have been taken forward in various ways, affecting not only the Pacific but how World Heritage conservation is practiced more generally. In particular, community participation in all stages of implementation of the Convention was championed by Aotearoa/ New Zealand during their term as Chair of the World Heritage Committee in 2007 in which they represented interests of the Pacific Island region. Under the leadership of Tumu Te Heuheu, paramount chief of Ngati Tuwharetoa, Aotearoa/New Zealand successfully proposed the addition of a fifth 'C' for Community to the four strategic objectives of the World Heritage Committee - Credibility, Conservation, Capacity-building and Communication - that frame planning and funding of World Heritage programs (UNESCO 2007b).

\section{Customary systems in management}

The elevation of 'community' as a strategic objective of World Heritage Committee stands alongside efforts to incorporate community, and cultural aspects more broadly, in other international conservation programs. Several programs focussed on conservation of natural heritage have worked to incorporate cultural aspects: as values to be managed (e.g. sacred aspects of 'natural' sites); as ways of managing (drawing upon traditional ecological knowledge); and as ways of engaging community (e.g. community conserved areas). There is an increasing bank of resources that describe best practice management in this regard including: Indigenous and Traditional Peoples and Protected Areas - Principles, Guidelines and Case studies (Beltrán et al. 2000); Indigenous and Local Communities and Protected Areas: Towards Equity and Enhanced Conservation (Borrini-Feyerabend et al. 2004) or Indigenous Peoples and Community Conserved Areas(ICCAs) - Guidelines towards appropriate recognition and support (IUCN 2008); Guidelines for the protection of Sacred Natural Sites - Guidelines for Protected area Managers (Wild and 
McLeod 2008); and Integrated Conservation-Development Project methodologies (ICDPs) (see West and Brockington 2006; and Clark, Bolt and Campbell 2008, for recent discussions of these). Changing institutional practices relate not only to state-managed protected areas, but affect the way NGOs go about their in-country activities (see Hails 2007 for a discussion of community based conservation within World Wildlife Fund). These approaches are evolving as projects run their course and attract critical attention (see West and Brockington 2006 for a review of relevant critiques). A register of Indigenous and Community Conserved Areas currently being established by the World Conservation Monitoring Centre (see Corrigan and Granziera 2010) should enable a greater appreciation of the types and range of these initiatives.

This body of conservation literature offers useful tools for heritage managers including ways of doing conservation that are sensitive to community aspirations. These guidelines are not written to be politically correct, they draw on real cases to provide ways of working between different world-views, with the overall aim of improving conservation practices. It is worth emphasising however the hybrid nature of these initiatives. The fuzziness of the language sometimes obscures the outside involvement in these local projects: 'community'-based conservation projects are often the result of an internationally developed methodology when initiated through non-government and government aid programmes. For example, Govan et al. (2006:63) speak of locally managed marine areas in contrast to 'global approaches', thus localising what has been an initiative driven from outside.

Following his observation of conservation projects in Melanesia, Simon Foale notes:

... conservation of the scientific, cultural, and other heritage values of coral reefs in these countries is and will continue to be inextricably bound up with aid programs and NGO projects, and therefore becomes the responsibility of a broad range of actors, requiring the synthesis of a broad range of intellectual disciplines. (Foale 2008:32)

It is the multiple interests bundled together that lead to what we identify these approaches as a 'customary systems in management' approach. Although these interests coalesce around a local community, very often the governance arrangements and the articulations of management are those fashioned by outside interests and expectations. Where locals have control and are comfortable operating within a Western management framework, the use of customary systems of decisionmaking and environmental knowledge in management can be a powerful combination. Lisa Palmer (2006) highlights an example of this in her discussion of natural resource management, where under 'nation to nation' agreements in Canada members of the Cree nation exercise the right to determine how timber is harvested on their lands.

Since 1994 (for cultural sites) and 1999 (for natural sites, following inscription of East Rennell Island $)^{1}$ the World Heritage Committee has afforded customary management of World Heritage properties the same status as management by government institutions:

All properties inscribed on the World Heritage List must have adequate long-term legislative, regulatory, institutional and/or traditional protection and management to ensure their safeguarding ... States Parties should demonstrate adequate protection at the national, regional, municipal, and/or traditional level for the nominated property. (UNESCO 2011 Paragraph 97)

\footnotetext{
1 Previous versions of the Operational Guidelines had required that sites nominated to the World Heritage List must have 'adequate legal protection and management mechanisms (cultural sites)' or 'adequate long-term legislative, regulatory or institutional protection (natural sites)'. Very early versions of the guidelines had requirements for legal protection but not for management. This was amended to 'adequate legal and/or traditional protection and management' in 1994 for cultural sites and in 1999 for natural sites.
} 
When a site is nominated to the World Heritage List, the State Party is required to provide 'a clear explanation of the way this protection operates to protect the property' (UNESCO 2009, Paragraph 97). The Guidelines specify how various aspects of a site should be managed, but deliberately do not provide a concrete definition for traditional management, stating rather:

Management systems may vary according to different cultural perspectives ... They may incorporate traditional practices, existing urban or regional planning instruments, and other planning control mechanisms, both formal and informal. (UNESCO 2011, Paragraph 110)

To date, only a handful of sites have been inscribed under customary management systems. For the most part these are systems of participatory management that include one or more local communities, such as examples of joint and co-management, in Uluru-Kata Tjuta and Kakadu National Parks in Australia, Traditional Owners are formally integrated within a park management system making decisions about conservation of their lands. In these cases a national park (with all the associated apparatus of government) was established prior to land being handed back to traditional custodians. Tongariro National Park, in Aotearoa/New Zealand provides a different case study, where tangata whenua ('the people of the land') made the case for establishing a national park from the outset. Protection of the sacred mountains of Tongariro was negotiated in the 1870s during colonisation, when the then Paramount chief 'gifted' his tapu lands to be tapu ('sacred and protected') under Queen Victoria. As one of the first national parks, following not long after Yellowstone, management is through national government administration, and the paramount chief (at present Sir Tumu te Heuheu) sits on the park board.

These examples highlight an important distinction between 'customary systems used in management' and 'customary systems of management'. Customary systems with in a Western conservation management framework are continually negotiated but framed by outside agendas and concepts of conservation practice. 'Customary systems of management' mean living in landscapes, conserving important places and negotiating uses of resources through local customary practices. Integrating local customary systems within Western models of conservation may be an effective approach in many parts of the world, and especially for places where traditional owners are no longer resident and/or dependent on access to land and resources for their livelihoods. In the Pacific Islands, on the other hand, continuing traditional land tenure and resource use means conservation is framed by the local cultural practices in decision making and ways of understanding and being in the landscape. Across the Pacific region customary owners cannot be invited to participate in conservation of their traditional lands, rather they mediate any activities that take place on their land. Discussing natural heritage conservation in the Solomon Islands, in particular, anthropologist Eduard Hviding stresses:

... biodiversity conservation initiatives in most cases are bound to focus on species and environments that are already culturally and economically significant for somebody else: those who live in, subsist on and, in many cases claim property rights to the 'species' and 'areas', which for them are more likely to be 'resources' and 'territories'. (Hviding 2006:72)

\section{Towards customary systems of management in the Pacific}

We return here to World Heritage and the example of the East Rennell World Heritage site in the Solomon Islands. East Rennell is a small and remote upraised coral island in the south west of the Solomon Islands that was inscribed in the World Heritage List for its natural values in 1998 under the then Criterion N (ii), now known as Criterion ix. The formal justification for inscription states: 
East Rennell, as a stepping stone in the migration and evolution of species in the western Pacific, is an important site for the science of island biogeography. Combined with the strong climate effects of frequent cyclones, East Rennell is a true natural laboratory for scientific study. (http://whc.unesco.org/en/ list/854)

Although internationally recognised only for these natural values, the customary owners of the property, approximately 800 people, live within the World Heritage area in four villages along the edge of Lake Tegano, a freshwater lake that occupies over half of the World Heritage area. For them, East Rennell is their cultural landscape, one that their Polynesian ancestors settled from somewhere to the east in the distant past. Subsistence agriculture, fishing and hunting underpin the economy and the community relies on forest products for most construction materials. The traditional land tenure system divides the land into tribal areas (Kakaiangá) each under the authority of one of the island's chiefs (Hakahua). The lake is regarded as common property.

The World Heritage nomination for East Rennell briefly mentioned the history and culture of the island however neither the cultural values of the landscape nor the traditional system of authority and land tenure were described. The International Union for the Conservation of Nature (IUCN), the advisory body to the World Heritage Committee for properties of natural values, advised that the nomination 'breaks new ground in terms of nominating a natural site that is under customary land ownership, that has no formalised legal basis and for which the object is sustainable resource use' (IUCN 1998). On inscribing the property, the Committee agreed that customary protection and management of the natural values of the property should be supported and noted that the rights of customary owners and customary law are acknowledged in the Constitution of the Solomon Islands and the Solomon Islands Customs Recognition Act (1995). However the Committee on the advice of IUCN reiterated the need for a locally-developed management plan that documented the customary system of protection and a national World Heritage Protection Bill to be prepared by the Solomon Islands government.

Civil unrest in the Solomon Islands resulted in almost no communication between the customary owners on East Rennell and the outside world from 2000-2005. In 2005 a delegation from UNESCO visited the island and found that although no progress had been made in development of a management plan, the intrinsic conservation values of the site were not unduly threatened (Tabbasum and Dingwall 2005). IUCN noted at the time of inscription, customary ownership 'can be more conducive to conservation than if the land was under control of a distant government office' (IUCN 1998:81).

A management plan for East Rennell was finally completed in 2007 utilising the 'Resource Management Objectives and Guidelines for East Rennell' prepared at the time of nomination and with support from the UNESCO World Heritage Fund (Wein 2007). The management plan was prepared through a participatory process with the community and recognises the central role of traditional owners in conservation of the biodiversity of East Rennell. However, it takes what we identify as a customary system in management approach, integrating customary owners within management framed by the Western scientific values about 'nature'. The customary systems that have protected the values of the property are not documented or utilised in the management plan although it does suggest that 'documentation of past traditional management practices for Rennell is needed to provide an appropriate blend of traditional practices and contemporary community-based management practices' (Wein 2007:16).

On East Rennell, like many other places in the Pacific, the conservation initiative including the development of the World Heritage nomination has been driven by non-local interests. In satisfying the requirements of the World Heritage Committee and IUCN, the values of the property have been articulated according to Western scientific discourse with little investigation 
of how these values may intersect with local understandings of landscape and resources. Under the 2007 management plan, the local management authority is the East Rennell World Heritage Trust Board (now reformed as the Lake Tegano World Heritage Site Association or LTWHSA), a representative community organisation established in a previous form during the development of the nomination in the late 1990s. In accordance with the management plan, the LTWHSA with the assistance of international volunteers has implemented a community engagement process and education programs (Gabrys in press), raising community awareness of World Heritage and conservation of natural resources. But many in the community continue to be unaware of the existence of the management plan and those that are, are unclear about what it may mean in their daily lives. In discussions with the community of East Rennell in 2010, Smith (2011) found a widespread misconception that Rennellese culture was included in the values of the World Heritage inscription - the community does not distinguish nature from culture - and an urgent need for all documentation relating to the World Heritage values and their management to be translated into the Rennellese language. Further although LTWHSA is an inclusive and representative body in a Western democratic sense, the relationship of LTWHSA to the traditional authority, the East Rennell Council of Chiefs is unclear. This appears fundamental to future management of the property as it is the Council of Chiefs who are the decision making authority in relation to land and resource disputes.

Although the inscription of East Rennell on the World Heritage List was a landmark in international recognition of customary land tenure, at the time there were no established precedents or processes within World Heritage for articulating or assessing customary management systems for the protection of 'natural' values. Customary access to, use and management of resources is embedded within wider cultural practices of the Rennellese that have conserved the 'natural' values of the island. In East Rennell the local community, with the support of LTWHSA and the Council of Chiefs, is now considering a project to record their traditional knowledge to provide a framework in which World Heritage values of the site are articulated and managed through cultural practices of the community. This will be a 'catch-up' process initiated and directed by the community. The livelihoods of the community are under pressure, food security is tenuous and the increasing need and desire to participate in the cash economy is placing pressure on the island's resources. The World Heritage status of the island has not and will not alter this situation but the local community consider that greater recognition of their unique culture in the World Heritage system will protect not only the values for which their island is considered to be World Heritage but the reasons why those values exist.

Customary management within the holistic cultural framework of Pacific communities makes sense, yet it continues to be at odds with the way institutional structures approach heritage conservation, within national governments; in international non-governmental organisations; and through international conventions. Organisations such as the South Pacific Regional Environment Program and the Secretariat of the Pacific Community have responsibility for natural or cultural heritage conservation respectively at the regional level. Most Pacific Island governments have separate ministries or agencies responsible for natural and cultural heritage and the funding programs of many international non-government organisations reinforce these divisions.

This is also the case in the World Heritage system despite the original logic behind the World Heritage Convention, bringing together nature conservationists and those concerned with the protection of cultural property and monuments. To some extent this has been addressed through the inclusion of 'cultural landscape' as a category of site in the World Heritage system in 1993. Cultural landscapes are defined as properties that reflect 'the combined works of man [sic] and nature' and explicitly recognise the cultural values that have created and given meaning to 
landscapes. Not surprisingly, a number of Pacific Islands states have included cultural landscapes in their tentative lists of potential World Heritage sites. Various places in the Pacific undoubtedly have outstanding 'natural' values but there are no 'natural' landscapes in the Pacific Islands and as the recent 'Maupiti Declaration' (2009) affirms, for many Pacific Islanders, the ocean is a cultural seascape. ${ }^{2}$

As mentioned previously, since the inscription of East Rennell, four further properties in independent Pacific Island states have been successfully nominated to the World Heritage List. Chief Roi Mata's Domain, Vanuatu and Kuk Early Agricultural site Papua New Guinea were inscribed as cultural landscapes in 2008 and managed according to what we identify as customary systems of management. Bikini Atoll in the Marshall Islands, also a cultural landscape, and Phoenix Islands Protected Area, Kiribati, a primarily marine property, were inscribed in 2010 with management plans taking customary systems in management approaches. Notwithstanding that these four properties have very different management issues for example the tiny country of Kiribati is attempting to manage over 40 million ha of the Pacific Ocean while in Vanuatu a major threat to the values of Chief Roi Mata's Domain is the leasing of adjacent land for development, in each there is negotiation between customary land (or sea) owners and noncustomary legal mechanisms for protection is ongoing. There has not yet been sufficient time to assess the implications of their different management approaches for long-term protection of the sites.

In developing the management plan for Chief Roi Mata's Domain, Meredith Wilson writes that the act of engaging in conservation management planning can be an empowering one:

Throughout this process the project team has supported the community in developing a Plan of Management that is based upon the reinforcement of existing customary systems of marine and land tenure. The engagement of local communities in the development of appropriate management regimes ... is an approach that ensures that the local community remains in control of the management of its own resources. (Wilson 2006:7)

'Remaining in control' is key here. If the establishment of a formal heritage property/ protected area requires new management entities (and it does not follow that this is necessarily the case) these entities should be coherent with existing local governance structures. Decision making within the Lelepa region of Vanuatu in which Chief Roi Mata's Domain (CRMD) is located is vested in the power of the chiefs. CRMD is managed as a joint venture of the land owning groups, the Chiefs and landowners having approved the formation of the World Heritage and Tourism Committee to implement the management plan. The World Heritage and Tourism Committee is composed of representatives from the villages and external advisors including the Vanuatu Cultural Centre (Wilson 2006; Wilson et al. in press). Similarly, the management plan for the Kuk Early Agricultural site specifies the use of traditional clans and relationship to land to appoint people responsible for management. Under the plan, heritage officers are drawn from, and proposed by, the three main clans that comprise the Kawelka customary owners. Each officer will be responsible for overseeing day-to-day activities and for ensuring compliance with the management plan within a discrete area of their clan's land (Muke et al. 2007). At the heart of the CRMD management plan is customary protection through the system of nafsan natoon ('local lore') that refers to socially prescribed behaviour in relation to certain people, places and things (Wilson 2006:22). The management plan attempts to document this system. The Kuk early agricultural site is of international significance as a site of early agriculture, inscribed on

2 The full text of the Ocean Declaration is available from: http://www.temanaotemoana.org/UserFiles/File/Maupiti\%20Ocean\%20 Declaration-Final.pdf 
the World Heritage List as an organically evolved cultural landscape that demonstrates changing land use practices through time. As Muke et al. (2007:332) point out, management of the site through continuation of traditional agriculture and its transformations is considered to enhance the significance of the site.

A challenge, particularly for conservationists (and for the World Heritage Committee), is examining how traditional management structures do the equivalent work of a Western conservation programme. Community approaches to conservation may seem inconsistent or incompatible when viewed through the lens of an international conservation regime. Assessment is coloured by preconceived expectations of best-practice in management. This includes requirements for governance, such as committees, reports and plans, which stand as representative of proper management. For example, when assessing a nomination the World Heritage Committee takes the presence of an explicit heritage administrative structure and planning documents as signifying that the site is being 'managed'. These may not be superfluous to a coherent customary management system, but a site being well managed under customary tenure may not have the need for such heritage management structures and tools (cf. Govan et al. 2009).

National governments too require bureaucratic flexibility in this regard. To fulfil reporting requirements under the World Heritage Convention, Pacific governments are required to explain to the World Heritage Committee how sites are being protected and provide evidence of this, while at the same time, acknowledging a devolved local customary management system. National legislation for the protection of natural and cultural heritage in the region is at best limited and ad hoc. Given that the rights of customary owners are enshrined in the Constitutions of many Pacific Island States, the usefulness of heritage legislation developed outside the region as a model for the Pacific states is limited.

The approach adopted for the Kuk Early Agricultural Site provides an example of how customary law may support and may itself be supported through legislation. Under the Constitution of Papua New Guinea land is automatically owned by local communities who traditionally resided in an area. Although at Kuk the land has been formally owned by the Government under a lease arrangement since 1968, through the management plan the government acknowledges the rights of the Kawelka customary owners and other groups to occupy and use the land in traditional ways (Muke et al. 2007:330). The framework for legal protection for the World Heritage property is a combination of national legislation including the National Cultural Property (Preservation) Act 1965 (PNG), the Papua New Guinea Conservation Areas Act (1978) in combination with an Organic Law, enacted by the local Provincial Government, provides a means of reinforcing customary management in legal terms:

The Organic Law empowers local communities to generate binding laws to protect their own cultural and natural resources (Section 43). Laws are generated by local communities, approved by the local government council...endorsed by the provincial government... and subsequently made into law by the NEC. (Government of Papua New Guinea 2007:63-4)

This Organic Law (not yet in force but see Denham in press) provides a structure for representing local practices in terms expected in conservation management planning. It is also a means of legally binding and promoting ongoing traditional uses within the local community (who, we should be clear to emphasise, have varied and conflicting attitudes to ownership and use of the site. See Strathern and Stewart 1998; Denham in press). In the Solomon Islands there is still no national heritage legislation to protect World Heritage sites. However, legislation in some ways similar to an Organic Law is being drafted for East Rennell, in the form of a Provincial Government Resource Management Ordinance. This will provide for protection of natural 
resources through prohibition on activities having adverse environmental effects identified in a Resource Order requested by customary owners and enforced by the Provincial Government. Under the draft Ordinance, a customary land owning group may make its own policy statements and plans regarding the use of resources.

The Provincial Government Ordinance may serve to reinforce the central role of customary owners in management, but the system of customary land tenure on East Rennell (essential to the Ordinance) and the relationship of cultural understandings of the landscape to this legal framework remain to be documented. Bringing differing world views together is not straightforward. Paige West's work in Papua New Guinea describes the confusion between locals and conservationists participating in a Wildlife Conservation project where notions of 'species' and 'biodiversity' have no equivalent in local understandings of the environment (West and Brockington 2006). However, Simon Foale's work in Melanesia led him to reflect that rather than contribute to the potential loss of local ecological knowledge through assessing and articulating heritage values in non-local terms, the act of defining heritage values in local terms may be a useful means of recording and (re)discovering local environmental knowledge (Foale 2008).

Given this, a more appropriate approach to protection through legislation with its genesis in the region may be that of the Model Law for the Protection of Traditional Knowledge and Expressions of Culture developed by the Secretariat of the Pacific Community (2006) as a framework for governments considering national legislation for the protection of Indigenous culture. Although the emphasis is on intangible and movable heritage, the Model Law has been designed to recognize and strengthen the continuing traditional land tenure in the region and the provisions supporting customary and traditional governance are relevant to our discussion of landscapes. These include:

Encourage the use of customary laws and systems and traditional governance and decision making systems as far as possible, and recognise that communities will always be entitled to rely exclusively or in addition upon their own customary and traditional forms of protection ...; and,

Recognise that the continued uses, exchange, transmission and development of Traditional Knowledge and Expressions of Culture within the customary context by the relevant traditional community, as determined by customary laws and practices, should not be restricted or interfered with. (SPC 2004:13)

\section{Discussion}

The realities of living in an area and conserving it at the same time require negotiation, whatever the system of management. Local social and economic circumstances dictate the priorities of a community and in turn inform the processes and outcomes of conservation. In the case of East Rennell the remoteness of the island and difficulty of access has limited development, fostered the continuation of traditional gardening and use of local resources and, as a consequence, protected the island's biodiversity. On the other hand, the remoteness of the island limits communication and makes access to education, employment opportunities and the cash economy extremely difficult and, in the face of increasing food insecurity on the island, is a potential trigger for unsustainable resource use such as logging and mining.

The designation of World Heritage means little in itself if the customary owners are not satisfied. Local priorities, not least of which is sustainable livelihoods, direct community engagement with non-local heritage conservation projects and regimes. Customary systems of decision making and management may assist communities to negotiate pressures such as those faced by East Rennell. However, any romanticised notions of traditional ecological practices held by outsiders need to be tempered with concern for livelihoods and the realisation that conservation, as it is understood by 
non-locals, might not necessarily be sympathetic with local expectations of heritage conservation. Furthermore, aspects of customary management may conflict with outsider interests especially in relation to social equity. Opportunities for the participation of all community members may be lacking in customary management approaches especially given that in the Pacific traditional authority may be inherited and older men are commonly privileged in decision making.

More broadly, provincial and national government and regional organisation (under resourced as they may be) need to ensure that the legislative and institutional structures they create promote and integrate customary owners and traditional practices. To achieve this, there is a real need for better coordination and integration of cultural and natural heritage protection and conservation in the region. A practical beginning is to work on methodologies for conserving cultural and natural values in an integrated system of heritage management that would complement the ecological landscape assessment work of conservationists with cultural mapping techniques and community definition of values and aspirations. Members of the community of East Rennell have expressed their wish to develop a project to record their cultural values including land tenure, environmental knowledge, traditional resource use, crafts, songs and dance to provide an umbrella framework in which their 'natural' values would be managed (Smith 2011).

To date the World Heritage sites in the Pacific have not been inscribed for sufficient time for longer-term issues in the protection and management regimes of the properties to arise. It is perhaps too early even to examine whether the structures defined on paper actually represent the way decisions are made in practice. Nevertheless, engagement has been productive in the sense that it has helped to broaden practices under the World Heritage Convention. Over time this may lead to different approaches within the Pacific through new ways of structuring the relationship between customary land managers and the state, and new ways of forming alliances in the conservation of sites of local and global heritage value. Considering Community as the 5th ' $\mathrm{C}$ ' strategic objective of the World Heritage Committee is more than promoting community consultation or including community issues in management frameworks, it is also about who is driving the conservation project, who initiated it, and whether it meets local needs and aspirations. In defining mechanisms for customary management we seek a meaningful and practical articulation of community.

\section{References}

Beltrán, J. 2000. Indigenous and traditional peoples and protected Areas: Principles, guidelines and case studies. IUCN World Commission on Protected Areas Best Practice Protected Area Guidelines Series No.4.

Borrini-Feyerabend, G., Kothari, A. and Oviedo, G. 2004. Indigenous and local communities and protected areas: Towards equity and enhanced conservation. IUCN, Gland.

Clark, S., Bolt, K. and Campbell, A. 2008. Protected areas: an effective tool to reduce emissions from deforestation and forest degradation in developing countries? World Conservation Monitoring Centre: UNEP Working paper, 16 May 2008 Revision.

Corrigan, C. and Granziera, A. 2010. A handbook for the Indigenous and community conserved areas registry. World Conservation Monitoring Centre - United Nations Environment Program. Version 1.

Denham, T. In press. Building institutional and community capacity for World Heritage in Papua New Guinea: The Kuk Early Agricultural Site and Beyond. In: Smith, A. (ed.), World Heritage in a sea of islands. World Heritage papers. UNESCO, Paris.

Foale, S. 2008. Conserving Melanesia's coral reef heritage in the face of climate change. Historic Environment 21(1):29-36. 
Gabrys, K. In press. Community and governance in the World Heritage property of East Rennell. In: Smith, A. (ed.), World Heritage in a sea of islands. World Heritage papers. UNESCO, Paris.

Govan, H., Tawake, A., Tabunakawai, K. Jenkins, A., Lasgorceix, A., Techera, E., Tafea, H., Kinch, J., Feehely, J., Ifopo, P., Hills, R., Alefaio, S., Meo, S., Troniak, S., Malimali, S., George, S., Tauaefa, T., Obed, T. 2009. Community conserved areas: A review of status and needs in Melanesia and Polynesia. ICCA regional review for CENESTA /TILCEPA /TGER /IUCN/ GEF-SGP.

Govan, H., Tawake, A. and Tabunakawai, K. 2006. Community-based marine resource management in the South Pacific. Parks 16(1):63-67.

Hails, C. 2007. The evolution of approaches to conserving the World's Natural Heritage: The experiences of WWF. International Journal of Heritage Studies 13(4):365-379.

Hviding, E. 2006. Knowing and managing biodiversity in the Pacific Islands: Challenges of environmentalism in Marovo Lagoon. International Social Studies Journal 187.

IUCN. 1998. Documentation on World Heritage Properties (Natural). http://whc.unesco.org/en/ sessions/22COM/documents/

IUCN. 2008. Indigenous Peoples' and Community Conserved Areas (ICCAs) -Guidelines towards appropriate recognition and support.

Muke, J., Denham, T. and Genorupa, V. 2007. Nominating and managing a World Heritage Site in the highlands of Papua New Guinea. World Archaeology 39(3):324-338.

Palmer, L. 2006. 'Nature', place and the recognition of Indigenous Polities. Australian Geographer $37(1): 33-43$.

Papua New Guinean Government. 2007. The Kuk early agricultural site: A cultural landscape. Nomination for consideration as World Heritage Site. Ministry of Environment and Conservation, Port Moresby.

Secretariat of the Pacific Community. 2006. Guidelines for developing national legislation for the protection of traditional knowledge and expressions of culture based on the Pacific Model Law 2002. Noumea.

Smith A. In press. The Pacific 2009 World Heritage Program. In: Smith, A. (ed.), World Heritage in a sea of islands. World Heritage papers. UNESCO, Paris.

Smith A. 2011. East Rennell World Heritage Site: misunderstandings, inconsistencies and opportunities in the implementation of the World Heritage Convention in the Pacific Islands. International Journal of Heritage Studies 17(6):592-607.

Smith, A. and Jones, K. 2007. Cultural landscapes of the Pacific Islands. ICOMOS, Paris.

Strathern, A.J. and Stewart, P.J. 1998. Kuk Heritage: Issues and debates in Papua New Guinea. PNG National Museum, Port Moresby.

Tabbasum A. and Dingwall, P. 2005. Report on the mission to East Rennell World Heritage Property and Marovo Lagoon, Solomon Islands. 30 March-10 April, 2006 Unpublished report, UNESCO World Heritage Centre, Paris.

te Heuheu, T. M., Kawharu, M. and Tuiheiva, R. 2012. World Heritage and Indigeneity. World Heritage 62:44-50.

UNESCO. n.d. World Heritage Centre Activities - Pacific 2009 Programme. http://whc.unesco.org/en/ pacific2009

UNESCO. 1999. Report of the 22nd session of the World Heritage Committee, Tokyo. WHC-98/

CONF.203/18. UNESCO, Paris. 
UNESCO. 2007a. Appeal to the World Heritage Committee from Pacific Island state parties. http://whc. unesco.org/en/sessions/31COM/documents/ (Document: whc07-31com-11ce[1] Annex 1).

UNESCO. 2007b. Proposal for a 'Fifth C' to be added to the strategic objectives. http://whc.unesco.org/en/ sessions/31COM/documents/ (Document: whc07-31com-13be[1].

UNESCO. 1972. Convention concerning the protection of the world's cultural and natural heritage. Adopted by the UNESCO general conference at its seventeenth session.

UNESCO. 2009 Operational guidelines for the implementation of the World Heritage Convention. World Heritage Centre.

Vanuatu, Republic of. 2006. Chief Roi Mata's Domain. Nomination by the Republic of Vanuatu for inscription on the World Heritage List.

Wein, L. 2007. East Rennell World Heritage Site Management Plan. East Rennell World Heritage Trust Board, Solomon Islands.

West, P. and Brockington. D. 2006. Some unexpected consequences of protected areas: an anthropological perspective. Conservation Biology 20(3):609-616.

Wild, R. and McLeod, C. 2008. Sacred natural sites - Guidelines for protected area managers. Task Force on the Cultural and Spiritual Values of Protected areas in collaboration with UNESCO's Man and the Biosphere Programme. Best Practice Protected Area Guidelines Series No.16.

Wilson, M. 2006. Plan of Management for Chief Roi Mata's Domain (CRMD). Written on behalf of the World Heritage and Tourism Committee (WHTC), Lelepa Region.

Wilson, M., Ballard, C., Matanik, R. and Warry, T. In press. Community as the First C: Conservation and development through tourism at Chief Roi Mata's Domain, Vanuatu. In: Smith, A. (ed.), World Heritage in a sea of islands. World Heritage papers. UNESCO, Paris. 